Check for updates

Cite this: RSC Adv., 2017, 7, 41847

Received 31st July 2017

Accepted 23rd August 2017

DOI: $10.1039 / \mathrm{c} 7 \mathrm{ra0} 8422 \mathrm{f}$

rsc.li/rsc-advances

\section{Perovskite $\mathrm{La}_{2}(\mathrm{NiCu}) \mathrm{O}_{4}$ catalyst precursors for dry reforming of methane: effects of Cu-substitution on carbon resistance}

\author{
Meng Wang, (D) Tingting Zhao, Ming Li and Haiqian Wang* \\ Exploring low-cost catalysts with low carbon deposition and high activity for dry reforming of methane \\ (DRM) is of great importance in both industrial and academic fields. $\mathrm{La}_{2}\left(\mathrm{Ni}_{1-x} \mathrm{Cu}_{x}\right) \mathrm{O}_{4}(x=0.0-0.4)$ \\ perovskites were synthesized by a sol-gel self-combustion method and evaluated as catalyst precursors \\ for DRM. The reduced $\mathrm{La}_{2}\left(\mathrm{Ni}_{0.8} \mathrm{Cu}_{0.2}\right) \mathrm{O}_{4}$ shows optimal performance with negligible carbon deposition, \\ and the conversions of $\mathrm{CH}_{4}$ and $\mathrm{CO}_{2}$ are $73 \%$ and $80 \%$, respectively. The remarkably improved carbon \\ resistance of the reduced $\mathrm{La}_{2}\left(\mathrm{Ni}_{0.8} \mathrm{Cu}_{0.2}\right) \mathrm{O}_{4}$ is attributed to the small metallic particles obtained from the \\ reduced perovskite and the surface segregation of $\mathrm{Cu}$ in the metallic $\mathrm{Ni}-\mathrm{Cu}$ particles.
}

\section{Introduction}

Dry reforming of methane (DRM) has attracted much attention over the past decades considering its economic and environmental significance. DRM yields syngas with a $\mathrm{H}_{2} / \mathrm{CO}$ ratio of 1 , which is suitable for Fischer-Tropsch synthesis. This reaction consumes two greenhouse gases $\left(\mathrm{CH}_{4}\right.$ and $\left.\mathrm{CO}_{2}\right){ }^{\mathbf{1 , 2}}$ The main reactions of DRM are $^{3}$

$$
\begin{array}{cl}
\mathrm{CH}_{4}+\mathrm{CO}_{2} \rightleftharpoons 2 \mathrm{H}_{2}+2 \mathrm{CO} & \Delta H_{298}^{0}=247.3 \mathrm{~kJ} \mathrm{~mol}^{-1} \\
\mathrm{CO}_{2}+\mathrm{H}_{2} & \rightleftharpoons \mathrm{CO}+\mathrm{H}_{2} \mathrm{O} \quad \Delta H_{298}^{0}=41.2 \mathrm{~kJ} \mathrm{~mol}^{-1}
\end{array}
$$

These reactions need to be operated at high temperatures due to their endothermic nature. The conversion of $\mathrm{CO}_{2}$ is generally higher than that of $\mathrm{CH}_{4}$ and the product ratio of $\mathrm{H}_{2}$ / CO is less than 1 due to the reverse water-gas reaction (RWGS, eqn (2)).

The main concern over DRM is its carbon deposition, which originates from two side reactions: $\mathbf{~}^{\mathbf{4} 6}$

$$
\text { Methane decomposition: } \mathrm{CH}_{4} \rightleftarrows \mathrm{C}(\mathrm{s})+2 \mathrm{H}_{2}
$$$$
\Delta H_{298}^{0}=+75 \mathrm{~kJ} \mathrm{~mol}^{-1}
$$

The Boudouard reaction : $2 \mathrm{CO} \rightleftarrows \mathrm{C}(\mathrm{s})+\mathrm{CO}_{2}$

$$
\Delta H_{298}^{0}=-171 \mathrm{~kJ} \mathrm{~mol}^{-1}
$$

Eqn (3) is favored at higher temperatures and eqn (4) is favored at lower temperatures.

Hefei National Laboratory for Physical Sciences at the Microscale, University of Science and Technology of China, Hefei, Anhui 230026, People's Republic of China. E-mail: hqwang@ustc.edu.cn; Fax: +86-551-63606266; Tel: +86-551-63603770
Catalysts based on noble metals are reported to be highly active towards DRM, ${ }^{7}$ but their application is quite limited because of their high cost. Ni-based catalysts are more economical from a commercial viewpoint. However, Ni-based catalysts prepared by a conventional wet-impregnation method have large Ni particles and low resistance to carbon deposition..$^{8-11}$ Thus, developing Ni-based catalysts with high catalytic activity and carbon resistance remains an open question. It is reported that the addition of $\mathrm{Cu}$ to the impregnated $\mathrm{Ni}$ catalysts enhances the catalytic performance for DRM. ${ }^{12-14}$ Liu et al. ${ }^{12}$ reported that $\mathrm{NiCu} / \mathrm{Al}_{2} \mathrm{O}_{3}$ shows better carbon resistance than $\mathrm{Ni} / \mathrm{Al}_{2} \mathrm{O}_{3}$ because that $\mathrm{Cu}$ inhibits the dissolution of carbon in Ni. Both $\mathrm{Chen}^{\mathbf{1 3}}$ and $\mathrm{Lee}^{\mathbf{1 4}}$ reported that adding a proper amount of $\mathrm{Cu}$ into $\mathrm{Ni}$ enhanced the long-term stability for DRM.

Moreover, it is reported that a highly dispersed Ni catalyst can be prepared by the so-called "solid phase crystallization" method, where Ni is "extracted" from solids with well-defined structures (such as perovskites with $\mathrm{Ni}$ at the B-site) after reduction. ${ }^{15}$ Using this method, catalysts obtained from $\mathrm{LaNiO}_{3}$ and $\mathrm{La}_{2} \mathrm{NiO}_{4}$ precursors have relatively small metal particles, showing enhanced catalytic activity and carbon resistance as compared with the impregnated ones.9,11 According to Gallego, ${ }^{11}$ reduced $\mathrm{La}_{2} \mathrm{NiO}_{4}$ shows better catalytic performance than reduced $\mathrm{LaNiO}_{3}$ due to the smaller Ni content. However, carbon deposition cannot be completely eliminated over reduced $\mathrm{La}_{2} \mathrm{NiO}_{4}{ }^{10}$ The major advantage of perovskites is that they can accommodate different elements at the A-site and/or Bsite without changing their lattice structure. ${ }^{16}$ Inspired by the improved carbon resistance of the impregnated $\mathrm{NiCu}$ catalysts, we substitute $\mathrm{Ni}$ with $\mathrm{Cu}$ in $\mathrm{La}_{2} \mathrm{NiO}_{4}$ to investigate the effects of $\mathrm{Cu}$ substitution on the catalytic performance towards DRM.

In this present work, $\mathrm{La}_{2}\left(\mathrm{Ni}_{1-x} \mathrm{Cu}_{x}\right) \mathrm{O}_{4}$ catalyst precursors were synthesized by glycine sol-gel self-combustion method. 
Remarkably improved carbon resistance is observed for the reduced $\mathrm{La}_{2}\left(\mathrm{Ni}_{0.8} \mathrm{Cu}_{0.2}\right) \mathrm{O}_{4}$. The effects of $\mathrm{Cu}$ substitution on the catalytic activity and carbon resistance for the DRM reactions are discussed.

\section{Experimental}

\subsection{Preparation}

$\mathrm{La}_{2}\left(\mathrm{Ni}_{1-x} \mathrm{Cu}_{x}\right) \mathrm{O}_{4}$ catalyst precursors were prepared by a selfcombustion method. ${ }^{17}$ The starting materials were $\mathrm{La}_{2} \mathrm{O}_{3}$, $\mathrm{Ni}\left(\mathrm{NO}_{3}\right)_{2} \cdot 6 \mathrm{H}_{2} \mathrm{O}$ and $\mathrm{Cu}\left(\mathrm{NO}_{3}\right)_{2} \cdot 3 \mathrm{H}_{2} \mathrm{O}$, which were purchased from Sinopharm Chemical Agent Company. All the chemicals were of analytical grade and used without any further purification. $\mathrm{La}_{2} \mathrm{O}_{3}$ was dissolved in distilled water by adding nitrate acid under constant stirring. $\mathrm{Ni}\left(\mathrm{NO}_{3}\right)_{2} \cdot 6 \mathrm{H}_{2} \mathrm{O}$ and $\mathrm{Cu}\left(\mathrm{NO}_{3}\right)_{2}-$ $\cdot 3 \mathrm{H}_{2} \mathrm{O}$ were added successively and a given amount of glycine $\left(\mathrm{NO}_{3}{ }^{-} / \mathrm{NH}_{2}=1\right)$ was added to the mixed aqueous solution of metal nitrates. The resulting solution was heated on a heating plate until self-combustion occurred. Then the powder precursors produced through combustion were calcined at $700{ }^{\circ} \mathrm{C}$ for $4 \mathrm{~h}$ under ambient atmosphere.

$\mathrm{Ni}_{0.8} \mathrm{Cu}_{0.2} / \mathrm{La}_{2} \mathrm{O}_{3}$ with $18 \mathrm{wt} \%$ metal loading, which is the same as that of $\mathrm{La}_{2}\left(\mathrm{Ni}_{0.8} \mathrm{Cu}_{0.2}\right) \mathrm{O}_{4}$, was prepared by the wetimpregnation method. Stoichiometric nickel and copper nitrate were dissolved in distilled water. $\mathrm{La}_{2} \mathrm{O}_{3}$ was added and the water was evaporated at $90{ }^{\circ} \mathrm{C}$ under continuous stirring. Then the residue was dried at $120^{\circ} \mathrm{C}$ overnight and calcined in air at $550{ }^{\circ} \mathrm{C}$ for $2 \mathrm{~h}$.

\subsection{Characterization}

$\mathrm{X}$-ray diffraction (XRD) analysis was performed by using an Xray diffractometer (TTR III, Rigaku Co., Japan) with standard $\mathrm{CuK} \alpha$ radiation $(\lambda=1.5406 \AA)$ in the range of $2 \theta=20-80^{\circ}$.

Temperature programmed oxidation (TPO) was carried out with a simultaneous thermal analyzer (STA 449 F3, NETZSCH, Germany) to determine the carbon deposition on the used samples and a temperature scheme was designed. Used catalysts of 5-15 mg were first heated to $800{ }^{\circ} \mathrm{C}$ and kept for $30 \mathrm{~min}$ under $\mathrm{N}_{2}$ atmosphere to decompose $\mathrm{La}_{2} \mathrm{O}_{2} \mathrm{CO}_{3}$. Then the sample was cooled down to room temperature under $\mathrm{N}_{2}$ atmosphere and TPO was conducted from 30 to $1000{ }^{\circ} \mathrm{C}$ in a gas flow of air.
The temperature-programmed reduction (TPR) was conducted by the same thermal analyzer (STA 449 F3, NETZSCH, Germany). During the test, samples of 10-15 $\mathrm{mg}$ were placed in an alumina crucible and heated in $5 \% \mathrm{H}_{2} / \mathrm{N}_{2}$ with a flow rate of $60 \mathrm{ml} \mathrm{min}{ }^{-1}$ and a heating rate of $5{ }^{\circ} \mathrm{C} \min ^{-1}$ from 30 to $1000{ }^{\circ} \mathrm{C}$.

Scanning electron microscopy (SEM, JSM-6301F, Hitach, Japan) and transmission electron microscopy (TEM, JEM-2011, JEOL, Japan) were employed to observe the microstructures of the samples. To identify the surface elemental composition and chemical status of the catalysts, XPS analyses were performed with monochromated $\mathrm{Al} \mathrm{K} \alpha$ radiation using ESCALAB 250 (Thermo-VG Scientific, U.S.).

\subsection{Catalytic reaction}

Catalytic activity evaluation was conducted in a quartz fixed-bed reactor (i.d. $=6 \mathrm{~mm}$ ), the catalysts were sieved to a 200-400 mesh size and charged in the reactor. The catalysts $(200 \mathrm{mg}$ ) were reduced in situ in $\mathrm{H}_{2}$ with a flow rate of $30 \mathrm{ml} \mathrm{min} \mathrm{mi}^{-1}$ at $700{ }^{\circ} \mathrm{C}$ for $1 \mathrm{~h}$ prior to DRM. DRM was conducted in a stream of $\mathrm{CH}_{4} / \mathrm{CO}_{2}=1$ at $750{ }^{\circ} \mathrm{C}$ for $5 \mathrm{~h}$ under atmospheric pressure. The flow rate of the $\mathrm{CH}_{4} / \mathrm{CO}_{2}$ stream was $60 \mathrm{ml} \mathrm{min}^{-1}$ (GHSV = $1.8 \times 10^{4} \mathrm{ml} \mathrm{g}^{-1} \mathrm{~h}^{-1}$ ). The reaction products were analyzed by a gas chromatography (GC9790, FULI, China). The conversions of $\mathrm{CH}_{4}$ and $\mathrm{CO}_{2}$ are defined as:

$$
\text { Conv } \mathrm{CH}_{4}=\frac{\left[\mathrm{CH}_{4}\right]_{\text {in }}-\left[\mathrm{CH}_{4}\right]_{\text {out }}}{\left[\mathrm{CH}_{4}\right]_{\text {in }}} \times 100 \%
$$

$$
\text { Conv } \mathrm{CO}_{2}=\frac{\left[\mathrm{CO}_{2}\right]_{\text {in }}-\left[\mathrm{CO}_{2}\right]_{\text {out }}}{\left[\mathrm{CO}_{2}\right]_{\text {in }}} \times 100 \%
$$

where $\left[\mathrm{CH}_{4}\right]_{\text {in }}$ and $\left[\mathrm{CO}_{2}\right]_{\text {in }}$ refer to the flow rates of the introduced $\mathrm{CH}_{4}$ and $\mathrm{CO}_{2}$, while $\left[\mathrm{CH}_{4}\right]_{\text {out }}$ and $\left[\mathrm{CO}_{2}\right]_{\text {out }}$ refer to the flow rates of $\mathrm{CH}_{4}$ and $\mathrm{CO}_{2}$ in the tail gas.

\section{Results}

\subsection{Catalytic performance and carbon deposition}

Fig. 1(a)-(c) show the $\mathrm{CH}_{4}, \mathrm{CO}_{2}$ conversions and $\mathrm{H}_{2} / \mathrm{CO}$ ratio as a function of reaction time during the DRM reactions over the reduced $\mathrm{La}_{2}\left(\mathrm{Ni}_{1-x} \mathrm{Cu}_{x}\right) \mathrm{O}_{4}$ with different $x$ values. According to
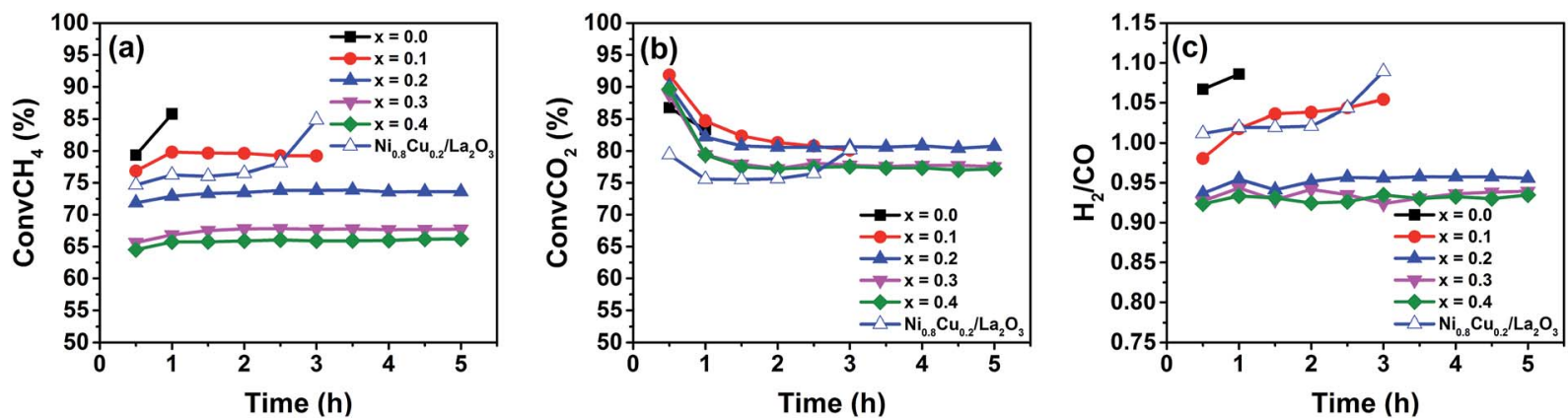

Fig. 1 Catalytic performance for the DRM reaction over the reduced $\mathrm{La}_{2}\left(\mathrm{Ni}_{1-x} \mathrm{Cu}_{x}\right) \mathrm{O}_{4}$ and the impregnated $\mathrm{Ni}_{0.8} \mathrm{Cu}_{0.2} / \mathrm{La}_{2} \mathrm{O}_{3}$ at $750{ }^{\circ} \mathrm{C}$ : (a) $\mathrm{CH}$ conversion, (b) $\mathrm{CO}_{2}$ conversion, and (c) $\mathrm{H}_{2} / \mathrm{CO}$ ratio as a function of reaction time. 
(a)

(b)
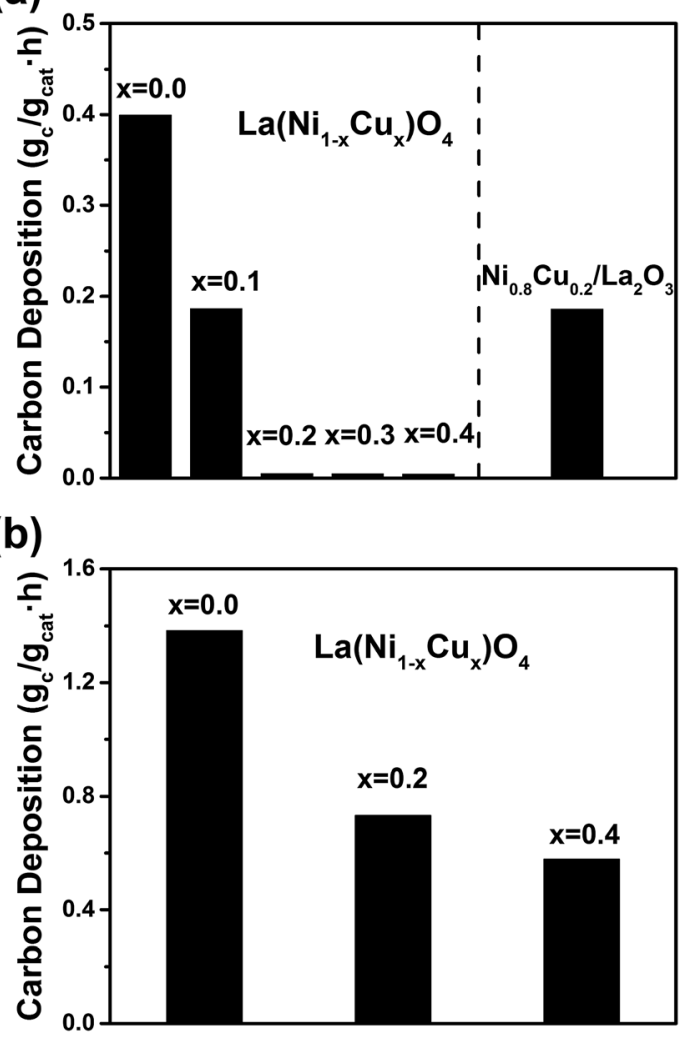

Fig. 2 Carbon deposition rates measured by TPO for (a) the DRM reaction, (b) the $\mathrm{CH}_{4}$ decomposition reaction.
Fig. 1(a), samples with $x=0.0$ and 0.1 show high initial $\mathrm{CH}_{4}$ conversions but the reactions cannot proceed beyond 1 and $3 \mathrm{~h}$ due to the reactor blocking. When $x$ increases to 0.2 , the $\mathrm{CH}_{4}$ conversion is stable at approximately $73 \%$ and no reactor blocking occurs during 5 h's test. Further increasing $x$ to 0.3 and 0.4 reduces the $\mathrm{CH}_{4}$ conversions. Fig. 1(b) shows that for the $x=$ 0.2-0.4 samples, the $\mathrm{CO}_{2}$ conversions are higher than those of $\mathrm{CH}_{4}$; while for the $x=0.0$ and 0.1 samples, the $\mathrm{CO}_{2}$ conversions are lower than those of $\mathrm{CH}_{4}$. The $\mathrm{H}_{2} / \mathrm{CO}$ ratios for the samples with $x=0.0$ and 0.1 are larger than unity (Fig. $1(\mathrm{c})$ ), indicating that methane decomposition (eqn (3)) is predominant in side reactions. Thus, carbon deposition should be responsible for the reactor blocking. While for the samples with $x=0.2-0.4$, the $\mathrm{H}_{2} / \mathrm{CO}$ ratios smaller than unity indicate the predominant occurrence of RGWS reaction in the side reactions. For comparison purpose, the $\mathrm{CH}_{4}, \mathrm{CO}_{2}$ conversions and $\mathrm{H}_{2} / \mathrm{CO}$ ratio of the impregnated $\mathrm{Ni}_{0.8} \mathrm{Cu}_{0.2} / \mathrm{La}_{2} \mathrm{O}_{3}$ are also shown in Fig. 1. It is seen that the reactor is partially blocked after $2 \mathrm{~h}$ and the $\mathrm{H}_{2} / \mathrm{CO}$ ratio is larger than unity. The partial blockage raises the reactor pressure and impedes the passage of the reactants, leading to the abnormal increase in the conversions.

The carbon deposition rates for DRM were measured by TPO and shown in Fig. 2(a). The $x=0.0$ sample suffers severe carbon deposition $\left(0.4 \mathrm{~g}_{\mathrm{c}} \mathrm{g}_{\text {cat }}{ }^{-1} \mathrm{~h}^{-1}\right)$, while the carbon deposition rate of the $x=0.1$ sample is approximately half of that of the $x=0.0$ sample. When $x$ increases to $0.2-0.4$, the carbon deposition is trivial, indicating the addition of $\mathrm{Cu}$ remarkably improves the carbon resistance of the reduced $\mathrm{La}_{2}\left(\mathrm{Ni}_{1-x} \mathrm{Cu}_{x}\right) \mathrm{O}_{4}$. Although the
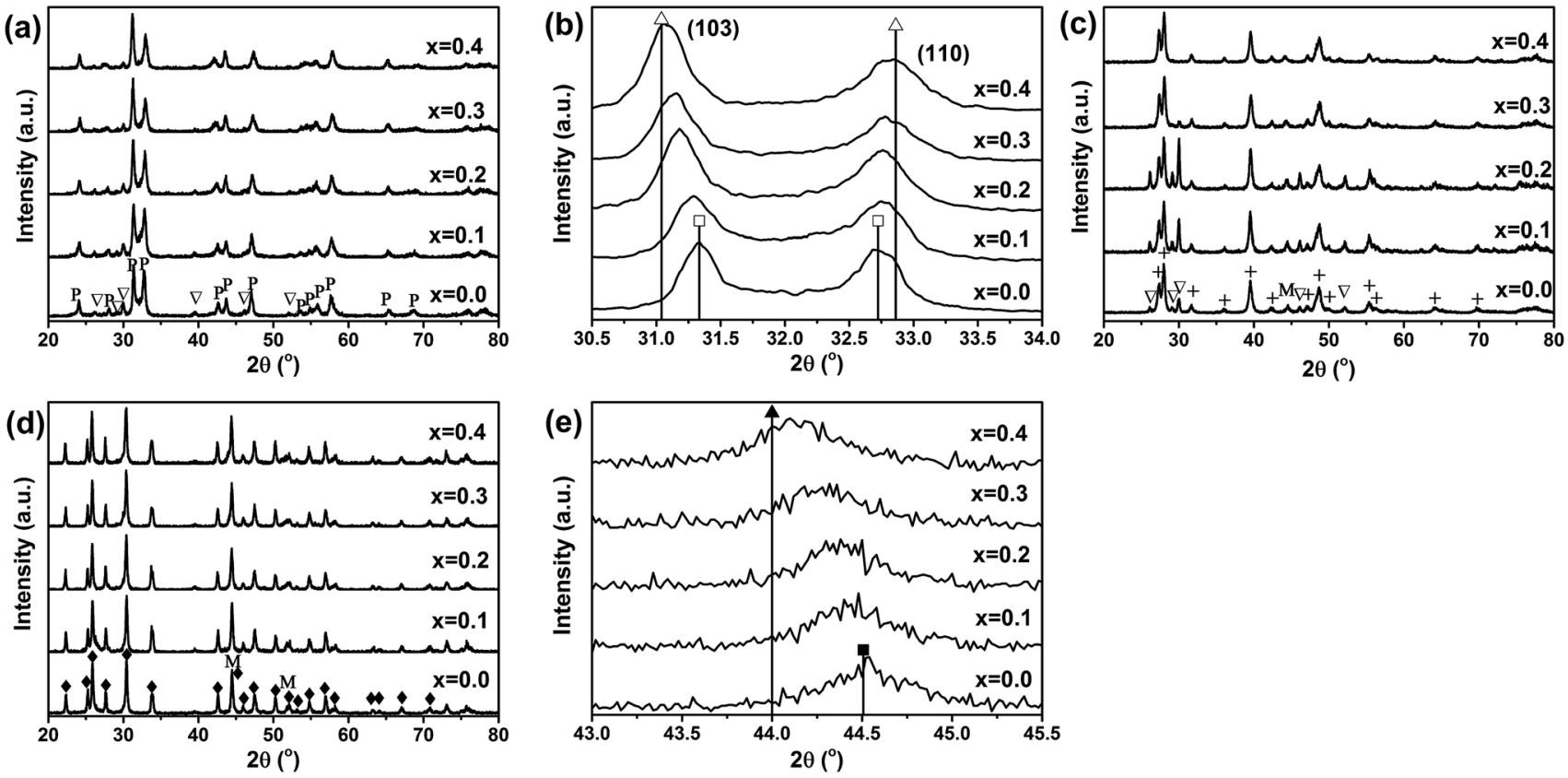

Fig. 3 (a) XRD patterns of fresh $\mathrm{La}_{2}\left(\mathrm{Ni}_{1-x} \mathrm{Cu}_{x}\right) \mathrm{O}_{4}$, (b) magnified (103) and (110) peaks of the perovskite $\mathrm{La}_{2}\left(\mathrm{Ni}_{1-x} \mathrm{Cu}_{x}\right) \mathrm{O}_{4}$ phase, (c) XRD patterns of as-reduced $\mathrm{La}_{2}\left(\mathrm{Ni}_{1-x} \mathrm{Cu}_{x}\right) \mathrm{O}_{4}$, (d) XRD patterns of used $\mathrm{La}_{2}\left(\mathrm{Ni}_{1-x} \mathrm{Cu}_{x}\right) \mathrm{O}_{4}$, and (e) magnified $\mathrm{Ni}(111)$ peaks of the as-reduced $\mathrm{La}_{2}\left(\mathrm{Ni}_{1-x} \mathrm{Cu}_{x}\right) \mathrm{O}_{4}(\mathrm{P}-$ perovskite phase referring to JCPDS 76-0055, $\nabla-\mathrm{La}_{2} \mathrm{O}_{3}$ referring to JCPDS 73-2141, + $-\mathrm{La}(\mathrm{OH})_{3}$ referring to JCPDS 36-1481, $\mathrm{M}-$ the $\mathrm{Ni}$ phase referring to JCPDS 04-0850, $-\mathrm{La}_{2} \mathrm{O}_{2} \mathrm{CO}_{3}$ referring to JCPDS 84-1963, $\square-$ standard $\mathrm{La}_{2} \mathrm{NiO}_{4}$ peak position from JCPDS 76-0055, $\triangle$ - standard $\mathrm{La}_{2} \mathrm{Ni}_{0.5} \mathrm{Cu}_{0.5} \mathrm{O}_{4}$ peak position from JCPDS 80-1075, $\mathbf{\square}$ - standard Ni peak position from JCPDS 04-0850 and $\boldsymbol{\Delta}$ - standard NiCu peak position from JCPDS 65-7246). 
Table 1 The lattice parameters of the tetragonal $\mathrm{La}_{2}\left(\mathrm{Ni}_{1-x} \mathrm{Cu}_{x}\right) \mathrm{O}_{4}$ unit cell

\begin{tabular}{lll}
\hline & \multicolumn{2}{l}{ Unit cell parameter $(\AA)$} \\
\cline { 2 - 3 } & $a=b$ & $c$ \\
\hline$x=0.0$ & 3.869 & 12.716 \\
$x=0.1$ & 3.863 & 12.742 \\
$x=0.2$ & 3.858 & 12.803 \\
$x=0.3$ & 3.852 & 12.936 \\
$x=0.4$ & 3.849 & 12.955 \\
$\mathrm{La}_{2} \mathrm{NiO}_{4}{ }^{a}$ & 3.868 & 12.697 \\
$\mathrm{La}_{2} \mathrm{Ni}_{0.5} \mathrm{Cu}_{0.5} \mathrm{O}_{4}{ }^{b}$ & 3.851 & 13.001
\end{tabular}

${ }^{a}$ Cell parameters of $\mathrm{La}_{2} \mathrm{NiO}_{4}$ (JCPDS 76-0055). ${ }^{b}$ Cell parameters of $\mathrm{La}_{2} \mathrm{Ni}_{0.5} \mathrm{Cu}_{0.5} \mathrm{O}_{4}$ (JCPDS 80-1075).

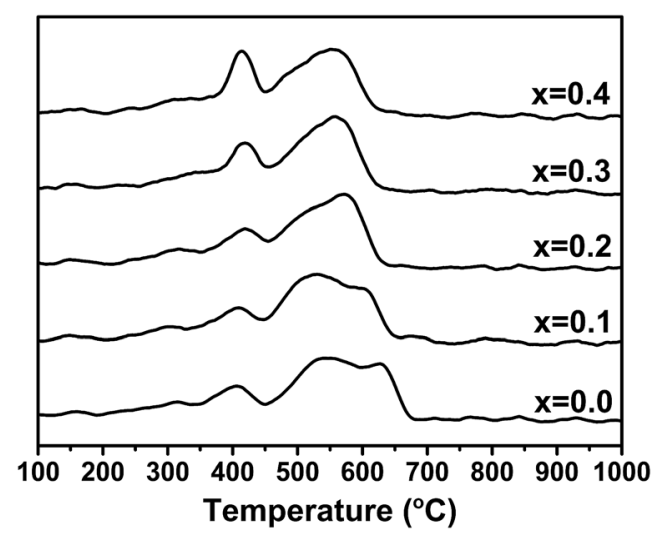

Fig. 4 TPR profiles of the fresh $\mathrm{La}_{2}\left(\mathrm{Ni}_{1-x} \mathrm{Cu}_{x}\right) \mathrm{O}_{4}$.

impregnated $\mathrm{Ni}_{0.8} \mathrm{Cu}_{0.2} / \mathrm{La}_{2} \mathrm{O}_{3}$ has the same metal loading and $\mathrm{Ni}: \mathrm{Cu}$ ratio as the reduced $\mathrm{La}_{2}\left(\mathrm{Ni}_{0.8} \mathrm{Cu}_{0.2}\right) \mathrm{O}_{4}$, it shows very severe carbon deposition. To further test the carbon resistance of the reduced perovskites, the decomposition of pure $\mathrm{CH}_{4}$ (eqn (3)) was conducted on the $x=0.0,0.2$ and 0.4 samples. The reaction was performed in a fixed-bed reactor under identical conditions to DRM. Complete deactivation due to carbon deposition occurs at 25, 60 and $75 \mathrm{~min}$ for the $x=0.0,0.2$ and 0.4 samples, respectively. Fig. 2(b) shows the carbon deposition rates of the $\mathrm{CH}_{4}$ decomposition reaction measured by TPO. It is seen that the addition of $\mathrm{Cu}$ reduces the carbon deposition rate significantly even for the decomposition of pure $\mathrm{CH}_{4}$. Thus, we conclude that the $\mathrm{La}_{2}\left(\mathrm{Ni}_{0.8} \mathrm{Cu}_{0.2}\right) \mathrm{O}_{4}$ perovskite is a better catalyst precursor for DRM, which shows high carbon resistance with stable and high catalytic activity.

\subsection{XRD analysis of the fresh, as-reduced and used catalysts}

Fig. 3(a) shows the XRD diffraction patterns of fresh $\mathrm{La}_{2}$ $\left(\mathrm{Ni}_{1-x} \mathrm{Cu}_{x}\right) \mathrm{O}_{4}$ catalysts with different $x$ values. All the fresh catalysts consist of a dominant amount of tetragonal $\mathrm{La}_{2}(\mathrm{NiCu})$ $\mathrm{O}_{4}$ and a small amount of $\mathrm{La}_{2} \mathrm{O}_{3}$. The lattice parameters of the tetragonal $\mathrm{La}_{2}\left(\mathrm{Ni}_{1-x} \mathrm{Cu}_{x}\right) \mathrm{O}_{4}$ unit cell determined from the XRD patterns are listed in Table 1 . To further confirm the incorporation of $\mathrm{Cu}$ in the perovskite lattice and the formation of $\mathrm{La}_{2}\left(\mathrm{Ni}_{1-x} \mathrm{Cu}_{x}\right) \mathrm{O}_{4}$, the (103) and (110) XRD peaks of the perovskite phase are magnified and shown in Fig. 3(b). The standard XRD peak positions of $\mathrm{La}_{2} \mathrm{NiO}_{4}$ ((JCPDS 76-0055)) and $\mathrm{La}_{2} \mathrm{Ni}_{0.5} \mathrm{Cu}_{0.5} \mathrm{O}_{4}$ (JCPDS 80-1075) are shown in Fig. 3(b) for reference purpose. The (103) peak shifts to lower angles while the (110) peak shifts to higher angles with the increase of $x$. This shift is due to the change in the lattice parameters of the tetragonal $\mathrm{La}_{2}\left(\mathrm{Ni}_{1-x} \mathrm{Cu}_{x}\right) \mathrm{O}_{4}$ unit cell, which is in agreement with the previous report. ${ }^{18}$ It is seen that as $x$ increases from 0.0 to 0.4 , both the lattice parameters and the peak positions of the $\mathrm{La}_{2}\left(\mathrm{Ni}_{1-x} \mathrm{Cu}_{x}\right) \mathrm{O}_{4}$ perovskite phase approach to those of the $\mathrm{La}_{2} \mathrm{Ni}_{0.5} \mathrm{Cu}_{0.5} \mathrm{O}_{4}$ (JCPDS 80-1075), indicating $\mathrm{Cu}$ has been incorporated into the B-site of the perovskite. Fig. 3(c) shows the XRD diffraction patterns of the as-reduced $\mathrm{La}_{2}\left(\mathrm{Ni}_{1-x} \mathrm{Cu}_{x}\right)$ $\mathrm{O}_{4}$ catalysts, which are reduced by $\mathrm{H}_{2}$ at $700{ }^{\circ} \mathrm{C}$ for $1 \mathrm{~h}$. All the perovskites decompose completely after the reduction. Metallic Ni phase, together with $\mathrm{La}_{2} \mathrm{O}_{3}$ and $\mathrm{La}(\mathrm{OH})_{3}$, is identified in the XRD patterns of the as-reduced catalysts. The formation of $\mathrm{La}(\mathrm{OH})_{3}$ may be due to the reaction between $\mathrm{La}_{2} \mathrm{O}_{3}$ and moisture. Fig. 3(d) shows the XRD patterns of the used catalysts. After DRM, $\mathrm{La}_{2} \mathrm{O}_{3}$ and $\mathrm{La}(\mathrm{OH})_{3}$ turn into $\mathrm{La}_{2} \mathrm{O}_{2} \mathrm{CO}_{3}$ due to the reaction between $\mathrm{La}_{2} \mathrm{O}_{3}$ and $\mathrm{CO}_{2}$. According to Gallego et al., ${ }^{9,11,19}$ the $\mathrm{La}_{2} \mathrm{O}_{3}$ support also participates in DRM by reacting with $\mathrm{CO}_{2}$ to form $\mathrm{La}_{2} \mathrm{O}_{2} \mathrm{CO}_{3}$, and $\mathrm{La}_{2} \mathrm{O}_{2} \mathrm{CO}_{3}$ may react with the surface carbon species formed on the Ni particles to produce CO. Fig. 3(e) shows
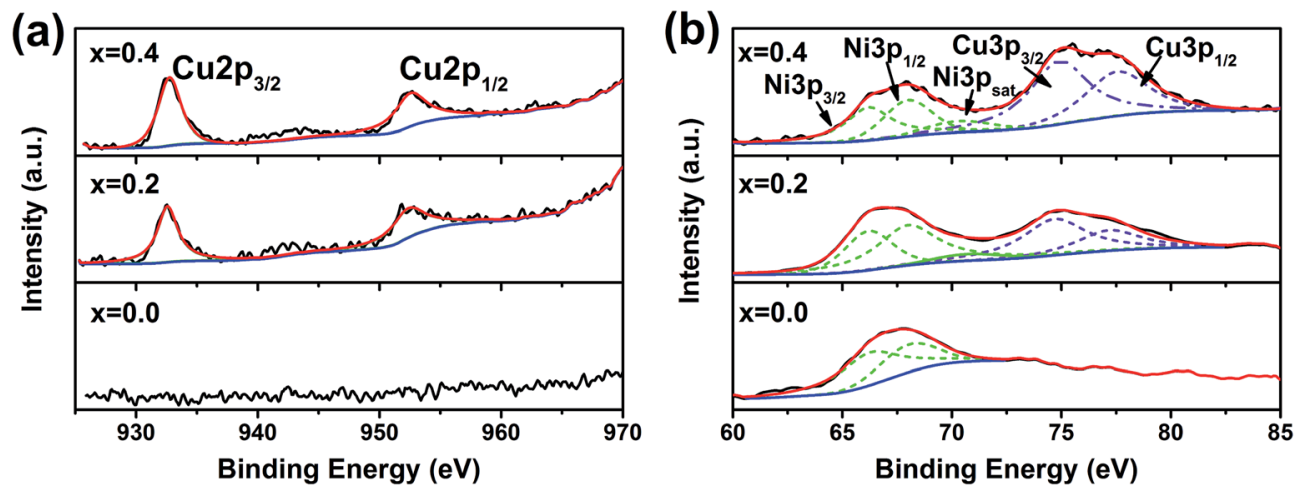

Fig. 5 XPS profiles of the used $\mathrm{La}_{2}\left(\mathrm{Ni}_{1-x} \mathrm{Cu}_{x}\right) \mathrm{O}_{4}$ with $x=0.0,0.2$ and 0.4: (a) Cu2p, (b) Ni3p and Cu3p. 
Table 2 Surface composition of the $\mathrm{Ni}-\mathrm{Cu}$ particles determined by XPS for the used $\mathrm{La}_{2}\left(\mathrm{Ni}_{1-x} \mathrm{Cu}_{x}\right) \mathrm{O}_{4}$ with $x=0.0,0.2$ and 0.4

$x$ in $\mathrm{La}_{2}\left(\mathrm{Ni}_{1-x} \mathrm{Cu}_{x}\right) \mathrm{O}_{4}$

(stoichiometry)

$x$ in

$\mathrm{Ni}_{1-x} \mathrm{Cu}_{x}$ (by XPS)

0.0

0.0000

0.4554

0.4

0.6486

the magnified XRD peaks of Ni (111) of the as-reduced catalysts with different $x$ values. The Ni (111) peak shifts to lower angles and the lattice parameter decreases from 3.5235 to $3.5553 \AA$ when $x$ increases from 0.0 to 0.4 . Thus, the formation of $\mathrm{Ni}-\mathrm{Cu}$ alloy is confirmed in the $x=0.1-0.4$ samples by comparing the lattice parameters with standard ones of $\mathrm{Ni}$
(111) (3.5238 Å, JCPDS 04-0850) and NiCu (111) (3.5615 A, JCPDS 65-7246).

\subsection{TPR profiles of the fresh catalysts}

The TPR profiles of the fresh $\mathrm{La}_{2}\left(\mathrm{Ni}_{1-x} \mathrm{Cu}_{x}\right) \mathrm{O}_{4}$ catalysts with different $x$ values are shown in Fig. 4 . All the catalysts are completely reduced below $700{ }^{\circ} \mathrm{C}$, which is in agreement with the above XRD analyses. The TPR profile of $\mathrm{La}_{2} \mathrm{NiO}_{4}$ agrees well with that reported by Liu et al. ${ }^{10}$ in which the peak centered at about $400{ }^{\circ} \mathrm{C}$ is attributed to the reduction of $\mathrm{NiO}$ and the peak in the range of $450-680{ }^{\circ} \mathrm{C}$ is assigned to the reduction of $\mathrm{La}_{2} \mathrm{NiO}_{4}$. As we can see, the peak related to the reduction of perovskites shifts to lower temperatures as the substitution degree of $\mathrm{Cu}$ increases, indicating that the incorporation of $\mathrm{Cu}$ increases the reducibility of the perovskites.
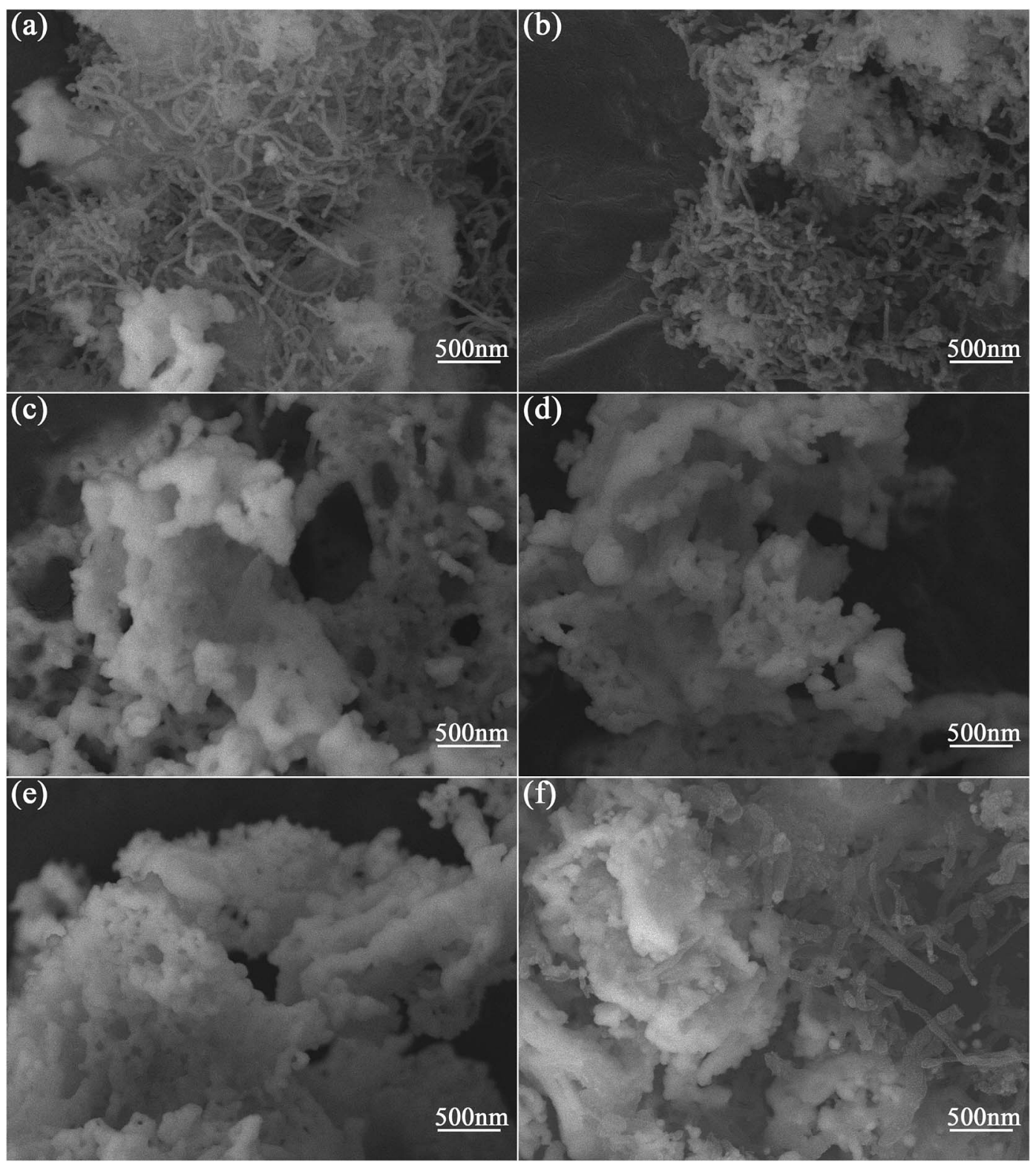

Fig. $6 \mathrm{SEM}$ images of the used $\mathrm{La}_{2}\left(\mathrm{Ni}_{1-x} \mathrm{Cu}_{x}\right) \mathrm{O}_{4}$ with $x=$ (a) 0.0, (b) 0.1, (c) 0.2, (d) 0.3, (e) 0.4, and (f) $\mathrm{Ni}_{0.8} \mathrm{Cu}_{0.2} / \mathrm{La}_{2} \mathrm{O}_{3}$. 


\subsection{XPS analysis of the used catalysts}

Fig. 5(a) shows the XPS spectra of $\mathrm{Cu} 2 \mathrm{p}$ for the used $\mathrm{La}_{2}$ $\left(\mathrm{Ni}_{1-x} \mathrm{Cu}_{x}\right) \mathrm{O}_{4}$ samples with $x=0.0,0.2$ and 0.4. As expected, we cannot observe any $\mathrm{Cu}$ peaks for the Cu-absent $x=0.0$ sample. For the Cu-present $x=0.2$ and 0.4 samples, $\mathrm{Cu} 2 \mathrm{p}_{3 / 2}(932.7 \mathrm{eV})$ and $\mathrm{Cu} 2 \mathrm{p}_{1 / 2}(952.5 \mathrm{eV})$ are clearly identified. The absence of large satellite peaks indicates the absence of $\mathrm{CuO}^{20}$ Thus, we conclude that $\mathrm{Cu}$ exists in its metallic form. Fig. 5(b) shows the spectra of Ni3p (together with Cu3p). For all three samples, $\mathrm{Ni} 3 \mathrm{p}$ can be deconvoluted into $\mathrm{Ni}_{3 / 2}(66.2 \mathrm{eV}), \mathrm{Ni} 3 \mathrm{p}_{1 / 2}$ $(68.0 \mathrm{eV})$ and a satellite peak, indicating the Ni element exists as metallic $\mathrm{Ni}^{21}$ Both $\mathrm{Ni}$ and $\mathrm{Cu}$ exist in their metallic forms, indicating that the perovskite precursors decompose completely under the reducing DRM conditions. The composition of the Ni-Cu alloy is determined by the XPS analysis and the results are listed in Table 2. It is worth noting that the atomic ratio of $\mathrm{Cu}$ in the $\mathrm{Ni}-\mathrm{Cu}$ alloy is much larger than the stoichiometric ratio of the $\mathrm{La}_{2}\left(\mathrm{Ni}_{1-x} \mathrm{Cu}_{x}\right) \mathrm{O}_{4}$ precursors. This is because the penetration depth of XPS is very small (1-5 nm). ${ }^{22}$ Thus, the composition determined by XPS reflects the surface composition of the alloy. The larger surface $\mathrm{Cu}: \mathrm{Ni}$ atomic ratio indicates an aggressive surface segregation of $\mathrm{Cu}$ in the $\mathrm{Ni}-\mathrm{Cu}$ alloy.

\subsection{Microstructures of the used catalysts}

Fig. 6 shows the SEM images of the used catalysts. Large amount of filamentous carbon can be observed for the $\mathrm{La}_{2}$ $\left(\mathrm{Ni}_{1-x} \mathrm{Cu}_{x}\right) \mathrm{O}_{4}$ samples with $x=0.0,0.1$ and $\mathrm{Ni}_{0.8} \mathrm{Cu}_{0.2} / \mathrm{La}_{2} \mathrm{O}_{3}$, while no carbon can be seen for the $x=0.2-0.4$ samples. This is in agreement with Fig. 2(a).

To gain further microstructural information of the used catalysts, TEM analyses were performed and the TEM images are shown in Fig. 7. Metallic particles dispersed on the support can be observed for all the samples. Carbon is present for the $x$

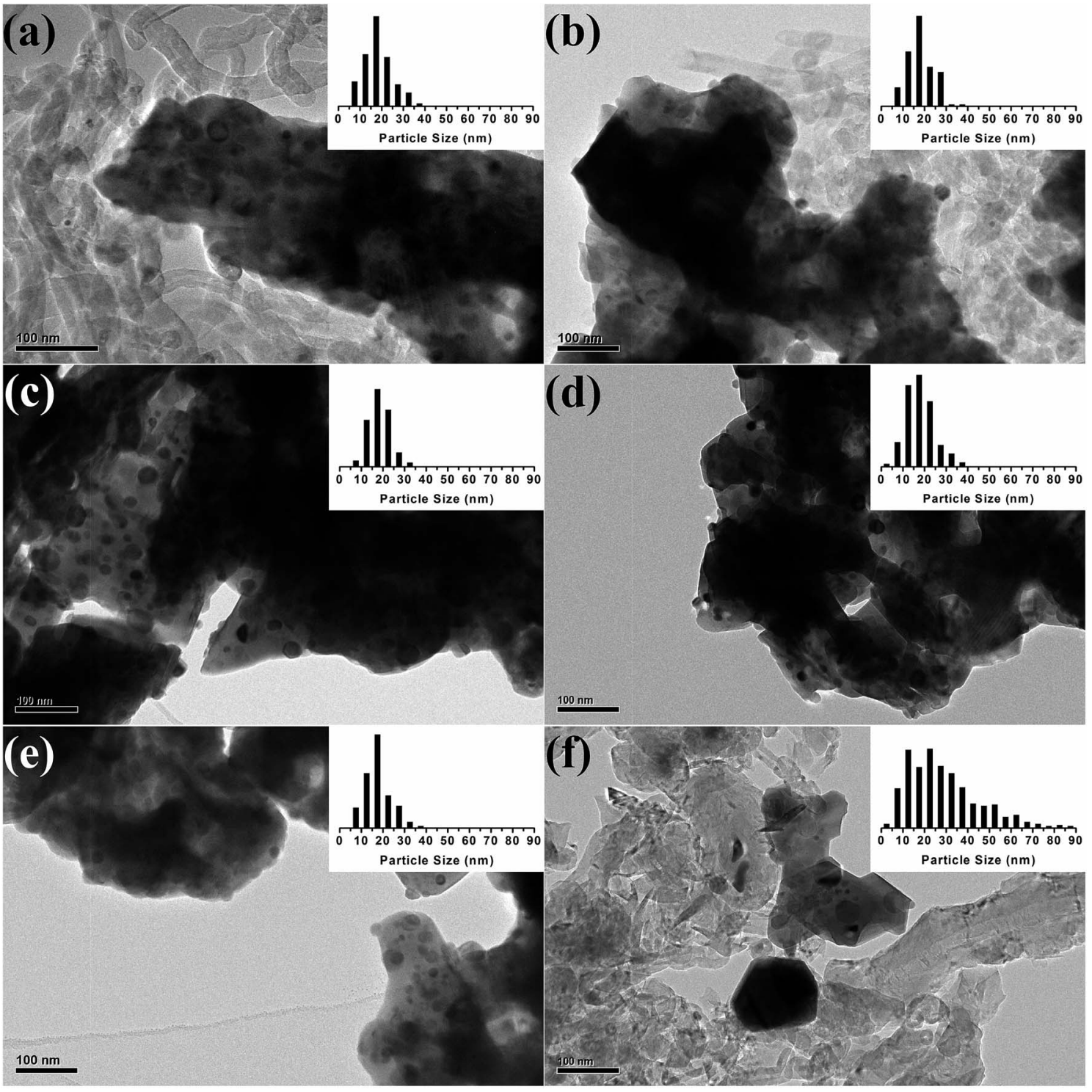

Fig. 7 TEM images of the used $\mathrm{La}_{2}\left(\mathrm{Ni}_{1-x} \mathrm{Cu}_{x}\right) \mathrm{O}_{4}$ with $x=$ (a) 0.0, (b) 0.1, (c) 0.2, (d) 0.3, (e) 0.4, and (f) $\mathrm{Ni}_{0.8} \mathrm{Cu}_{0.2} / \mathrm{La}_{2} \mathrm{O}_{3}$. 
$=0.0,0.1$ samples and $\mathrm{Ni}_{0.8} \mathrm{Cu}_{0.2} / \mathrm{La}_{2} \mathrm{O}_{3}$ but absent for the $x=$ 0.2-0.4 samples, which agrees with Fig. 2(a) and 6. The insets of Fig. 7 show the lateral size distributions of Ni particles which are statistically analyzed over more than 150 particles. It is interesting to note that although the reduced $\mathrm{La}_{2}\left(\mathrm{Ni}_{1-x} \mathrm{Cu}_{x}\right) \mathrm{O}_{4}$ catalysts show significant differences in carbon deposition, the size distributions $(0-40 \mathrm{~nm})$ of the metal particles are very similar. On the other hand, the impregnated $\mathrm{Ni}_{0.8} \mathrm{Cu}_{0.2} / \mathrm{La}_{2} \mathrm{O}_{3}$ shows a more disperse metal particle distribution $(0-90 \mathrm{~nm})$. The phenomenon that the metallic particle size of impregnated samples is larger than that of the reduced perovskites agrees with other reports. ${ }^{8-11}$

\section{Discussion}

According to our results, the reduced $\mathrm{La}_{2}\left(\mathrm{Ni}_{0.8} \mathrm{Cu}_{0.2}\right) \mathrm{O}_{4}$ shows the optimal catalytic performances with high catalytic activity and significantly improved carbon resistance.

Obviously, the reduced $\mathrm{La}_{2}\left(\mathrm{Ni}_{0.8} \mathrm{Cu}_{0.2}\right) \mathrm{O}_{4}$ shows better catalytic performance than the impregnated $\mathrm{Ni}_{0.8} \mathrm{Cu}_{0.2} / \mathrm{La}_{2} \mathrm{O}_{3}$. According to Fig. 7, the metallic particle size of the $x=$ 0.2 sample is smaller than that of the impregnated $\mathrm{Ni}_{0.8} \mathrm{Cu}_{0.2} /$ $\mathrm{La}_{2} \mathrm{O}_{3}$. It is generally accepted ${ }^{4,23}$ that the nucleation of the CNTs is through a dissolution-precipitation mechanism. Carbon, which has a high solubility in the nickel lattice, may dissolve into the nickel crystal and precipitate after supersaturation. According to Bengaard et al. ${ }^{24}$ large nickel particles favor graphite nucleation, since a graphite nucleus needs to be large enough to be stable. Thus, the large metallic particles of the impregnated $\mathrm{Ni}_{0.8} \mathrm{Cu}_{0.2} / \mathrm{La}_{2} \mathrm{O}_{3}$ lead to severe carbon deposition. Similar results were reported by Gallego et al. ${ }^{\mathbf{1 1}}$

However, it is interesting to note that although the metal particles show similar distribution (see the insets of Fig. 7), the reduced $\mathrm{La}_{2}\left(\mathrm{Ni}_{1-x} \mathrm{Cu}_{x}\right) \mathrm{O}_{4}$ catalysts show significant differences in carbon deposition. Thus, we cannot attribute the remarkably improved carbon resistance of the $x=0.2-0.4$ samples to the size effects of the metal particles. We have confirmed the surface segregation of $\mathrm{Cu}$ in the $\mathrm{Ni}-\mathrm{Cu}$ particles of the reduced $\mathrm{La}_{2}\left(\mathrm{Ni}_{1-x} \mathrm{Cu}_{x}\right) \mathrm{O}_{4}$ catalysts (see Table 2 ). The surface segregation of $\mathrm{Cu}$ in $\mathrm{Ni}-\mathrm{Cu}$ has also been widely reported. ${ }^{25-30}$ Moreover, Zhu et al. reported ${ }^{25}$ that the distribution of $\mathrm{Cu}$ on the $\mathrm{Ni}-\mathrm{Cu}$ particle surface is not uniform; $\mathrm{Cu}$ tends to segregate at corners and edges of the particle and both $\mathrm{Ni}$ and $\mathrm{Cu}$ tend to have neighbors of the same element. Thus, a cage-like structure of $\mathrm{Cu}$ forms on the surface of the $\mathrm{Ni}$ core and divides the surface of $\mathrm{Ni}$ ensembles into small areas. The small areas of Ni should be too small for the formation of stable graphite nucleus, thus suppresses the carbon deposition. Nevertheless, $\mathrm{Cu}$ is reported to be inert for $\mathrm{CH}_{4}$ adsorption and dissociation. ${ }^{31,32}$ Further increase of $x$ above 0.2 leads to reduced Ni-exposure on the metal surface, resulting in reduced catalytic activity.

\section{Conclusions}

$\mathrm{La}_{2}\left(\mathrm{Ni}_{1-x} \mathrm{Cu}_{x}\right) \mathrm{O}_{4}$ catalyst precursors were synthesized by glycine sol-gel self-combustion method. The reduced $\mathrm{La}_{2}\left(\mathrm{Ni}_{0.8} \mathrm{Cu}_{0.2}\right) \mathrm{O}_{4}$ shows optimal performance with negligible carbon deposition, and the conversions of $\mathrm{CH}_{4}$ and $\mathrm{CO}_{2}$ are $73 \%$ and $80 \%$, respectively. The remarkably improved carbon resistance of the reduced $\mathrm{La}_{2}\left(\mathrm{Ni}_{0.8} \mathrm{Cu}_{0.2}\right) \mathrm{O}_{4}$ is attributed to: (1) the smaller metallic particles of the reduced perovskite as compared with those of the impregnated catalyst; (2) the cage-like structure of surface segregated $\mathrm{Cu}$, which divides the surface of Ni ensembles into small areas and suppresses the formation of stable graphite nucleus. Thus, the perovskite $\mathrm{La}_{2}\left(\mathrm{Ni}_{0.8} \mathrm{Cu}_{0.2}\right) \mathrm{O}_{4}$ is a promising catalyst precursor for DRM.

\section{Conflicts of interest}

There are no conflicts to declare.

\section{Acknowledgements}

This work is supported by the National Natural Science Foundation of China (Grant No. 21427804).

\section{References}

1 I. Wender, Fuel Process. Technol., 1996, 48, 189-297.

2 D. L. Trimm, Catal. Rev.: Sci. Eng., 1977, 16, 155-189.

3 Y. Vafaeian, M. Haghighi and S. Aghamohammadi, Energy Convers. Manage., 2013, 76, 1093-1103.

4 D. L. Trimm, Catal. Rev., 1977, 16, 155-189.

5 C. H. Bartholomew, Catal. Rev., 2007, 24, 67-112.

6 M. C. J. Bradford and M. A. Vannice, Catal. Rev., 1999, 41, 142.

7 D. Pakhare and J. Spivey, Chem. Soc. Rev., 2014, 43, 78137837.

8 J. Rynkowski, P. Samulkiewicz, A. K. Ladavos and P. J. Pomonis, Appl. Catal., A, 2004, 263, 1-9.

9 G. S. Gallego, F. Mondragón, J.-M. Tatibouët, J. Barrault and C. Batiot-Dupeyrat, Catal. Today, 2008, 133, 200-209.

10 B. S. Liu and C. T. Au, Catal. Lett., 2003, 85, 165-170.

11 G. S. Gallego, F. Mondragón, J. Barrault, J.-M. Tatibouët and C. Batiot-Dupeyrat, Appl. Catal., A, 2006, 311, 164-171.

12 H. Liu, C. Y. Guan, X. Li, L. Y. Cheng, J. B. Zhao, N. H. Xue and W. P. Ding, ChemCatChem, 2013, 5, 3904-3909.

13 H. W. Chen, C. Y. Wang, C. H. Yu, L. T. Tseng and P. H. Liao, Catal. Today, 2004, 97, 173-180.

14 J. H. Lee, E. G. Lee, O. S. Joo and K. D. Jung, Appl. Catal., A, 2004, 269, 1-6.

15 R. Pereñíguez, V. M. González-DelaCruz, J. P. Holgado and A. Caballero, Appl. Catal., B, 2010, 93, 346-353.

16 S. Keav, S. Matam, D. Ferri and A. Weidenkaff, Catalysts, 2014, 4, 226-255.

17 G. Sierra Gallego, F. Mondragón, J.-M. Tatibouët, J. Barrault and C. Batiot-Dupeyrat, Catal. Today, 2008, 133-135, 200209.

18 K. K. Singh, P. Ganguly and C. N. R. Rao, Mater. Res. Bull., 1982, 17, 493-500.

19 G. N. Sierra Gallego, C. Batiot-Dupeyrat, J. L. Barrault and F. Mondragón, Ind. Eng. Chem. Res., 2008, 47, 9272-9278.

20 A. Galtayries and J. P. Bonnelle, Surf. Interface Anal., 1995, 23, 171-179. 
21 F. U. Hillebrecht, J. C. Fuggle, P. A. Bennett, Z. Zołnierek and C. Freiburg, Phys. Rev. B: Condens. Matter Mater. Phys., 1983, 27, 2179-2193.

22 C. Tang, Y. Kwon and J. Leckie, J. Membr. Sci., 2007, 287, 146156.

23 F. Abild-Pedersen, J. K. Nørskov, J. R. Rostrup-Nielsen, J. Sehested and S. Helveg, Phys. Rev. B: Condens. Matter Mater. Phys., 2006, 73, 115419.

24 H. S. Bengaard, J. K. Nørskov, J. Sehested, B. S. Clausen, L. P. Nielsen, A. M. Molenbroek and J. R. Rostrup-Nielsen, J. Catal., 2002, 209, 365-384.

25 L. Zhu and A. E. DePristo, J. Catal., 1997, 167, 400-407.
26 D. S. Mainardi and P. B. Balbuena, Langmuir, 2001, 17, 20472050.

27 S. N. Yee, T. T. Tsong and S. B. McLane, Surf. Sci., 1979, 84, 31-53.

28 P. R. Webber, C. E. Rojas, P. J. Dobson and D. Chadwick, Surf. Sci., 1981, 105, 20-40.

29 F. J. Kuijers and V. Ponec, Surf. Sci., 1977, 68, 294-304.

30 H. H. Brongersma, M. J. Sparnaay and T. M. Buck, Surf. Sci., 1978, 71, 657-678.

31 R. J. Gorte, S. Park, J. M. Vohs and C. Wang, Adv. Mater., 2000, 12, 1465-1469.

32 T.-J. Huang and S.-Y. Jhao, Appl. Catal., A, 2006, 302, 325-332. 